\title{
Impact of Vaccination on Distribution of T Cell Subsets in Antiretroviral-Treated HIV-Infected Children
}

\author{
Premrutai Thitilertdecha, ${ }^{1}$ Ladawan Khowawisetsut, ${ }^{2}$ Palanee Ammaranond, ${ }^{3}$ \\ Poonsin Poungpairoj, ${ }^{1}$ Varangkana Tantithavorn, ${ }^{1}$ and Nattawat Onlamoon ${ }^{1}$ \\ ${ }^{1}$ Department of Research and Development, Faculty of Medicine Siriraj Hospital, Mahidol University, Bangkok, Thailand \\ ${ }^{2}$ Department of Parasitology, Faculty of Medicine Siriraj Hospital, Mahidol University, Bangkok, Thailand \\ ${ }^{3}$ Department of Transfusion Medicine, Faculty of Allied Health Sciences, Chulalongkorn University, Bangkok, Thailand
}

Correspondence should be addressed to Nattawat Onlamoon; nattawat.onl@mahidol.ac.th

Received 4 January 2017; Accepted 27 April 2017; Published 12 June 2017

Academic Editor: Michael Hawkes

Copyright (c) 2017 Premrutai Thitilertdecha et al. This is an open access article distributed under the Creative Commons Attribution License, which permits unrestricted use, distribution, and reproduction in any medium, provided the original work is properly cited.

\begin{abstract}
Antiretroviral therapy (ART) is generally prescribed to patients with human immunodeficiency virus (HIV) infection with vaccination introduced to prevent disease complications. However, little is known about the influence of immunization on T cell subsets' distribution during the course of infection. This study aims to identify the impact of viral replication and immunization on naïve, effector, effector memory, and central memory T cell subpopulations in ART-treated HIV-infected children. Fifty patients were recruited and injected intramuscularly with influenza A (H1N1) 2009 vaccine on the day of enrollment (day 0) and day 28. Blood samples were collected for pre- and postvaccination on days 0 and 56 for analyzing $\mathrm{T}$ cell phenotypes by flow cytometry. Phenotypes of all T cell subsets remained the same after vaccination, except for a reduction in effector CD8 ${ }^{+} \mathrm{T}$ cells. Moreover, $\mathrm{T}$ cell subsets from patients with controllable viral load showed similar patterns to those with virological failure. Absolute CD4 count was also found to have a positive relationship with naïve $\mathrm{CD} 4^{+}$and $\mathrm{CD} 8^{+} \mathrm{T}$ cells. In conclusion, vaccination and viral replication have a little effect on the distribution of $\mathrm{T}$ cell subpopulations. The CD4 count can be used for prediction of naïve T cell level in HIV-infected patients responding to ART.
\end{abstract}

\section{Introduction}

Disease progression of human immunodeficiency virus (HIV) infection can be observed through changes in the numbers of $\mathrm{CD}^{+}$and $\mathrm{CD} 8^{+} \mathrm{T}$ cells. Depletion of $\mathrm{CD} 4^{+} \mathrm{T}$ cells occurs throughout three stages of HIV infection (i.e., acute infection, clinical latency, and acquired immune deficiency syndrome (AIDS)), whereas $\mathrm{CD} 8^{+} \mathrm{T}$ cells potentially increase in the first stage and remain during the second stage before depleting in the final stage [1]. Furthermore, monitoring a reduction in naïve $\mathrm{T}$ cell from both $\mathrm{CD} 4^{+}$and $\mathrm{CD} 8^{+}$populations together with an elevation of memory $\mathrm{CD} 8^{+} \mathrm{T}$ cells was useful to determine the disease progression in both HIVinfected adult patients [2] and HIV-infected children [3].

Antiretroviral therapy (ART) is normally used to suppress viral replication in HIV-infected patients whose CD4 count is consequently increased. Pakker et al. confirmed this increase in $\mathrm{CD}^{+} \mathrm{T}$ cells by finding that $\mathrm{CD} 4^{+}$and memory $\mathrm{CD}^{+} \mathrm{T}$ cells were significantly increased in the patients after receiving a highly active ART (HAART) through a redistribution of $\mathrm{T}$ cell subsets [4]. Plana et al. also studied HAART-treated patients and found increases in naïve and memory $\mathrm{CD}^{+} \mathrm{T}$ cell as well as a decrease in $\mathrm{CD} 8^{+} \mathrm{T}$ cells, suggesting that the earlier the treatment begins, the faster the $\mathrm{T}$ cell subset normalization is [5].

Although HAART is very effective at reducing viral load to an undetectable level, the immunological function does not fully recover to pre-HIV levels. Immunocompromised individuals, therefore, still have much higher chances of infection by other pathogenic viruses (e.g., influenza virus) and experience worse symptoms compared to healthy people. Immunization is then given to HIV-infected individuals to prevent severe complications; however, there is evidence showing that vaccination may also adversely affect 
the immunological status of HIV-infected people. Glesby et al. reported a decrease in $\mathrm{CD} 4^{+} \mathrm{T}$ cells led by influenza immunization [6], and Tasker et al. found the same significant reduction in $\mathrm{CD}^{+} \mathrm{T}$ cells in patients, 3 months after receiving a single shot [7]. Several publications have showed contradictory results, indicating that $\mathrm{CD}^{+} \mathrm{T}$ cells of patients injected with influenza vaccine had no significant change [8-11]. The influence of influenza immunization on $\mathrm{CD}^{+} \mathrm{T}$ cells in $\mathrm{HIV}$-infected patients thus remains controversial.

This study primarily aimed to pinpoint effects of immunization and viral replication on $\mathrm{T}$ cell distribution of both $\mathrm{CD}^{+}$and $\mathrm{CD}^{+}{ }^{+} \mathrm{T}$ cells together with their subsets (i.e., naïve, effector, effector memory (Tem), and central memory $(\mathrm{Tcm})$ cells) in ART-treated HIV-infected children. The study secondarily purposed to observe a relationship between the classical CD4 and CD8 counts with each $\mathrm{T}$ cell subset's frequency.

\section{Materials and Methods}

2.1. Study Population, Immunization, and Sample Collection. Fifty HIV-infected children aged between 6 months and 18 years old receiving ART at the Faculty of Medicine Siriraj Hospital, Mahidol University, Bangkok, Thailand, were recruited for the study. The Institution Review Board (IRB) of the Faculty of Medicine Siriraj Hospital approved the study, and written informed consent and parental consent were obtained from each subject prior to the study.

Two doses of influenza A (H1N1) 2009 vaccine were administered to the patients via an intramuscular route. Five hundred microliters and $250 \mu \mathrm{L}$ were administered to the patients aged above and below 3 years old, respectively. The first inoculation was given on the day of enrollment (day 0), and the second vaccination was given on day 28. Blood samples were collected twice: one before the first shot and another on 28 days after the second shot (day 56). Blood samples were collected in Vacutainer ${ }^{\mathrm{TM}}$ tubes containing either ethylenediaminetetraacetic acid (EDTA) or sodium heparin.

2.2. Routine Sample Analysis. Each blood sample was divided into two for analyses. The first analysis was a determination of $\mathrm{CD}^{+}$and $\mathrm{CD} 8^{+} \mathrm{T}$ cells by a flow cytometer and absolute lymphocyte counts by a routine complete blood count (CBC) test. The second analysis was an examination of HIV viral load by Abbott RealTime HIV-1 using plasma collected from an aliquot of the individual blood sample. The viral load value was then used to separate the patients into two groups, controller and noncontroller. Of the 50 patients, 37 patients who had undetectable viral loads $(<40$ copies $/ \mathrm{mL})$ at the enrollment and after the second vaccination (i.e., 56 days after the enrollment) were classified into the controller group. Thirteen subjects who failed those criteria were categorized into the noncontroller group.

2.3. Monoclonal Antibodies and Reagents for Flow Cytometric Analysis. Anti-human monoclonal antibodies (mAbs) and their conjugated fluorochromes including anti-human CD45RA conjugated with fluorescein isothiocyanate (FITC), anti-human CD4 conjugated with peridinin chlorophyll protein (PerCP), and anti-human CD62L conjugated with allophycocyanin (APC) were purchased from BD Biosciences (BDB, San Jose, CA) as well as FACS ${ }^{\mathrm{TM}}$ lysing solutions. Antihuman $\mathrm{CD} 3$ conjugated with PECy7 and anti-human CD8 conjugated with APC-Cy7 were obtained from BioLegend (San Diego, CA). Anti-human CCR7 conjugated with phycoerythrin (PE) was obtained from R\&D Systems (Minneapolis, $\mathrm{MN}$ ). All reagents were used at concentrations recommended by the manufacturers.

2.4. Immunofluorescent Staining Method and Flow Cytometric Analysis. Fifty microliters of an individual blood sample was stained with a mixture of mAbs containing CD45RA-FITC, CCR7-PE, CD4-PerCP, CD3PECy7, CD62L-APC, and CD8-APC-Cy7 and incubated in the dark at ambient temperature for 15 minutes. Two microliters of FACS lysing solution was then added into the mixture and incubated in the dark at ambient temperature for further 10 minutes before centrifugation at $350 \mathrm{~g}$ and $22^{\circ} \mathrm{C}$ for 5 minutes. The supernatant was discarded and cell pellets were then resuspended in $2 \mathrm{~mL}$ wash buffer (a mixture of phosphate-buffered saline (PBS) and 2\% fetal bovine serum). The sample was centrifuged at $350 \mathrm{~g}$ and $22^{\circ} \mathrm{C}$ for 5 minutes. After centrifugation, the supernatant was discarded and the cell pellets were resuspended in $300 \mu \mathrm{L}$ freshly prepared PBS containing $1 \%$ paraformaldehyde before being subjected to the flow cytometer.

The LSR II flow cytometer with FACSDiva software (BDB, San Jose, CA) was used to analyze the prepared samples with at least 100,000 lymphocytes per sample. Results of naïve, effector, Tem, and $\mathrm{Tcm}$ subsets from $\mathrm{CD} 4^{+}$and $\mathrm{CD} 8^{+} \mathrm{T}$ cell populations were analyzed using FlowJo software (Tree Star, San Carlos, CA).

2.5. Statistical Analysis. Data was expressed as an average $\pm \mathrm{SD}$ (standard deviation) and compared for statistical difference at $P<0.05$ using the Mann-Whitney $U$ test for evaluation between controller and noncontroller groups. Differences between different markers (CCR7 versus CD62L) and between blood samples before and after immunization were evaluated by using the Wilcoxon signed-rank test. Correlations among cell populations were assessed using the Spearman correlation test and considered to have a statistical correlation at $P<0.05$.

\section{Results}

3.1. Identification of $T$ Cell Subsets. To identify $\mathrm{CD} 4^{+}$and $\mathrm{CD}^{+} \mathrm{T}$ cell subsets including naïve, effector, Tem, and Tcm cells, two mAb combinations of CD45RA with CD62L and CD45RA with CCR7 have been commonly used. Nonetheless, there is no information concerning a difference of using these two $\mathrm{mAb}$ combinations in $\mathrm{T}$ cell subset identification. This study then observed the differences in terms of flow cytometric plot and cell number.

For phenotypic plot, subpopulations of $\mathrm{CD}^{+} \mathrm{T}$ cells (Figures 1(a) and 1(b)) and CD8 ${ }^{+} \mathrm{T}$ cells (Figures 1(c) and 1(d)) are characterized using the mAb combination of 


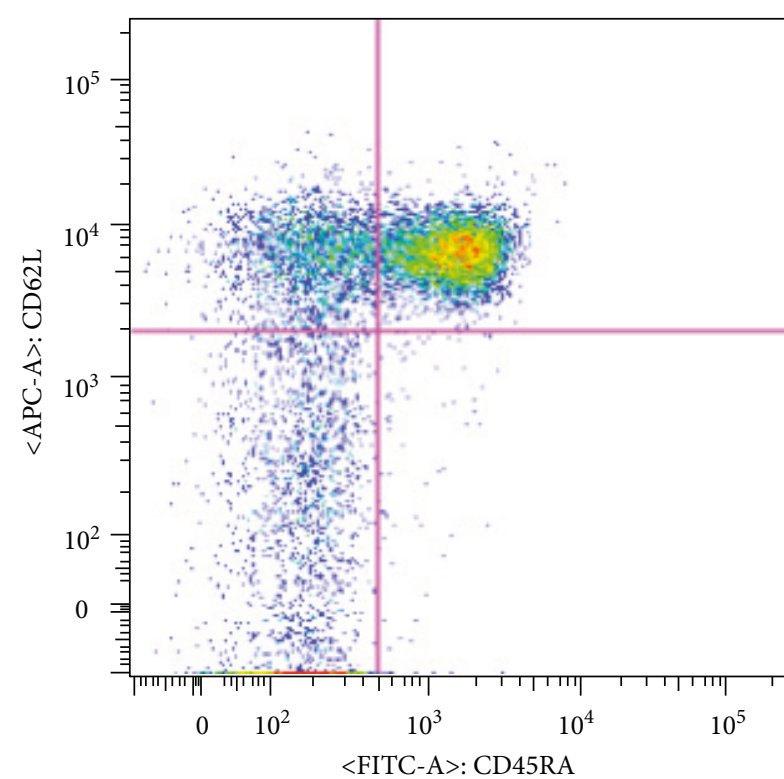

(a)

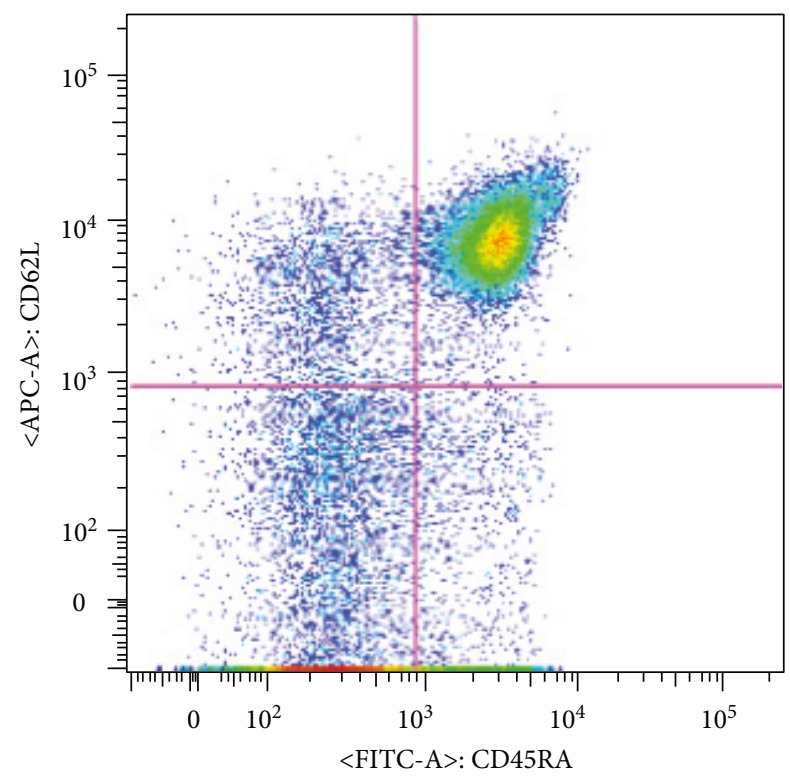

(c)

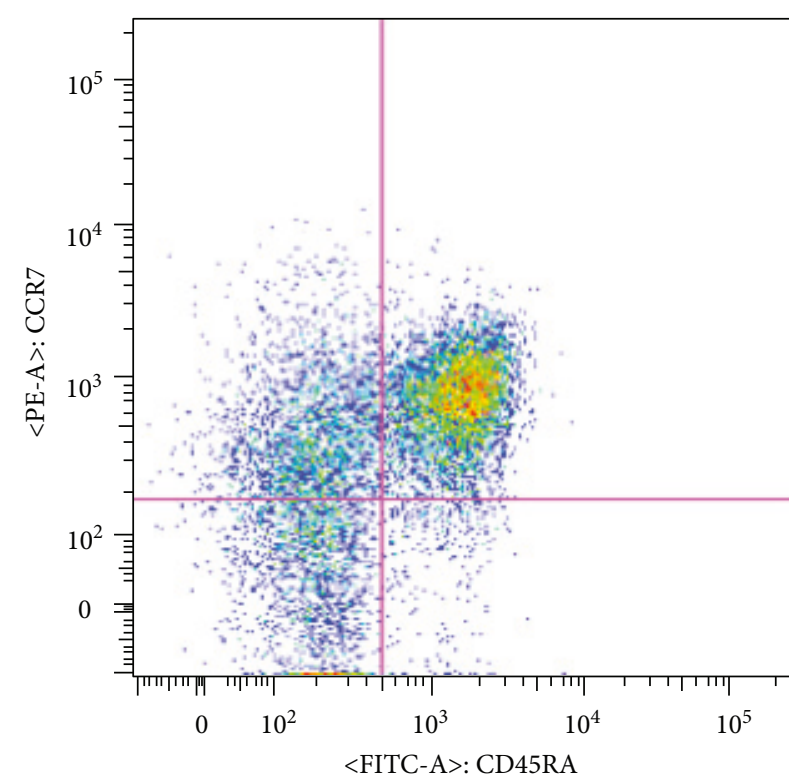

(b)

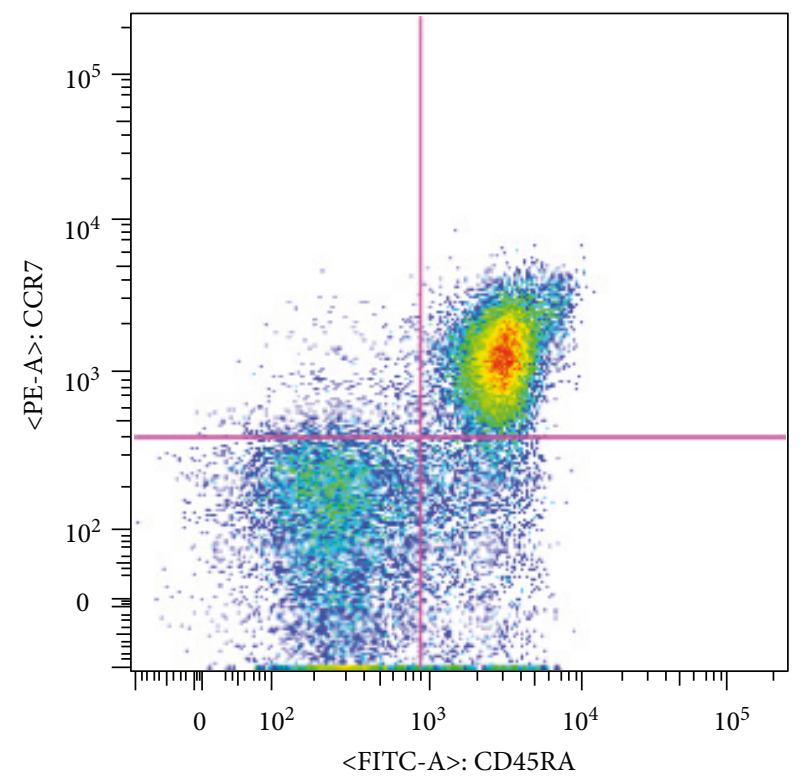

(d)

FIGURE 1: Representative profiles of T cell subsets identified by using CD45RA with CD62L compared to using CD45RA with CCR7 in CD4 ${ }^{+}$ $\mathrm{T}$ cells $(\mathrm{a}, \mathrm{b})$ and in $\mathrm{CD}^{+} \mathrm{T}$ cells $(\mathrm{c}, \mathrm{d})$.

CD45RA with CD62L compared to the one of CD45RA with CCR7. Naïve $\left(\mathrm{CD} 45 \mathrm{RA}^{+} \mathrm{CD}^{+} \mathrm{L}^{+}\right.$or $\mathrm{CD}^{+} 5 \mathrm{RA}^{+}$ $\left.\mathrm{CCR7}^{+}\right)$, Tem $\left(\mathrm{CD}^{2} 5 \mathrm{RA}^{-} \mathrm{CD}^{-} \mathrm{L}^{-}\right.$or $\left.\mathrm{CD}^{-} 5 \mathrm{RA}^{-} \mathrm{CCR7}^{-}\right)$, and $\mathrm{Tcm}\left(\mathrm{CD} 45 \mathrm{RA}^{-} \mathrm{CD}^{-} \mathrm{L}^{+}\right.$or $\left.\mathrm{CD} 4 \mathrm{RA}{ }^{-} \mathrm{CCR} 7^{+}\right)$cells were determined in both $\mathrm{CD} 4^{+}$and $\mathrm{CD} 8^{+}$, whereas effector cells (CD45RA+ CD62L- or CD45RA+ CCR7-) were presented in only $\mathrm{CD}^{+}$. Although the similarity of flow cytometric plots of $\mathrm{T}$ cell subsets using different $\mathrm{mAb}$ combinations was observed, the intensity of CD62L expression was slightly brighter.

With respect to cell number, the frequencies of $\mathrm{T}$ cell subsets of $\mathrm{CD}^{+}$and $\mathrm{CD}^{+}$from fifty HIV-infected children using the two different mAb sets were compared (Figure 2).
Naïve cells of $\mathrm{CD}^{+}$and $\mathrm{CD}^{+}$stained with CD62L were in greater amount than those stained with CCR7. In $\mathrm{CD} 4^{+}$population, the frequencies of Tem and Tcm cells from CD62L were higher and lower, respectively, than those from CCR7. These results of Tem and Tcm cells were vice versa in $\mathrm{CD}^{+}$population. A quantity of effector $\mathrm{CD} 8^{+} \mathrm{T}$ cells from CD62L was fewer than that from CCR7.

3.2. Effects of Viral Replication and Immunization on T Cell Subsets' Quantities. To date, an influence of HIV viral replication on T cell subpopulations remains equivocal. To determine this, all HIV-infected patients receiving vaccination were examined for their viral load levels and then divided 

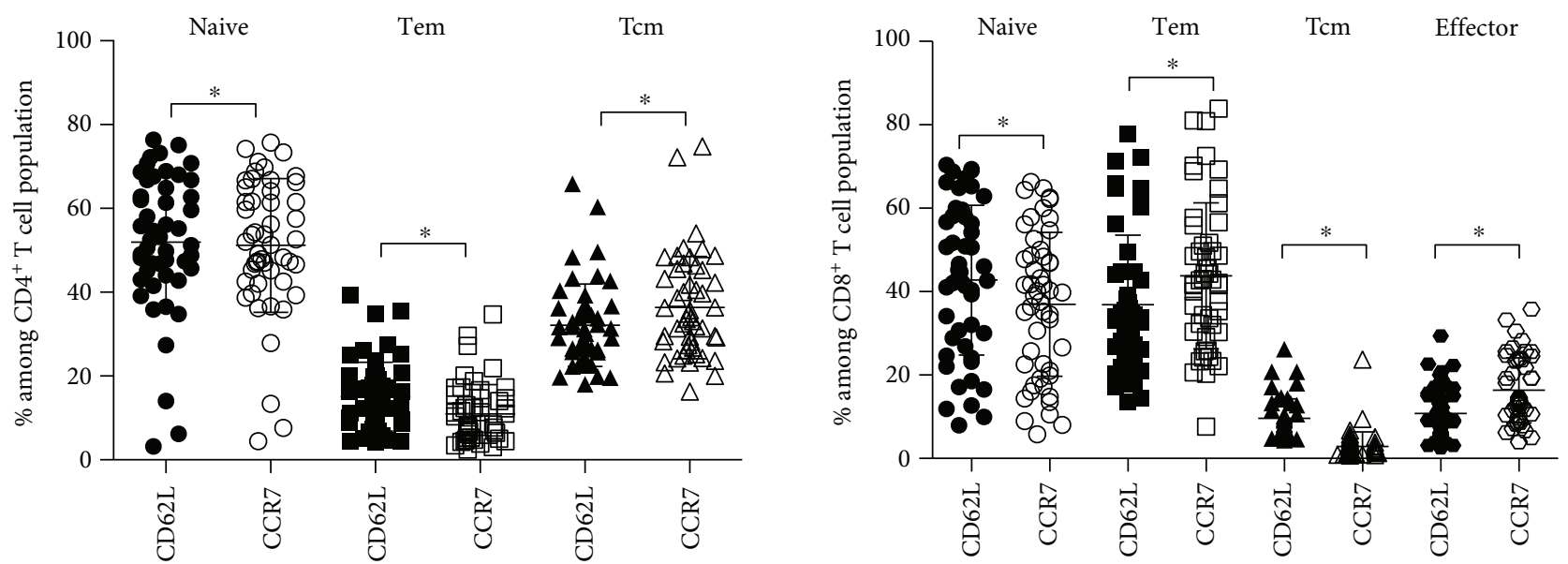

Figure 2: Comparison of $\mathrm{T}$ cell subsets of $\mathrm{CD} 4^{+}$and $\mathrm{CD}^{+} \mathrm{T}$ cells detected by using CD62L and CCR7. Line bar represents average $\pm \mathrm{SD}$; * indicates significant difference at $P<0.05$.

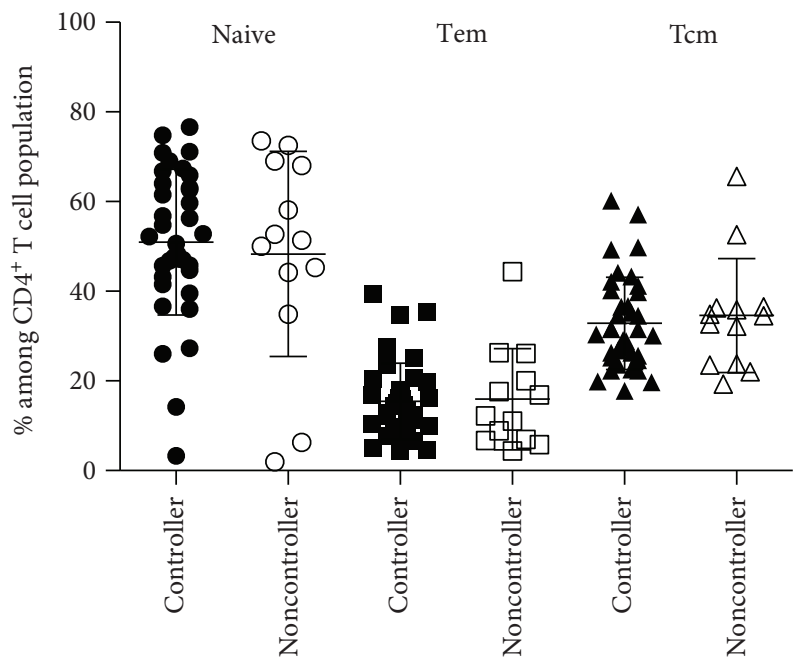

(a)

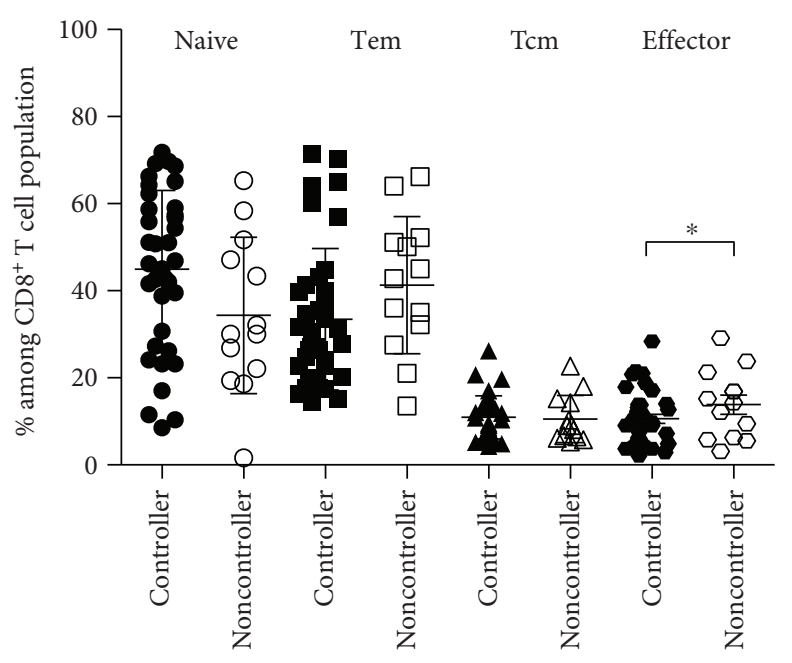

(c)

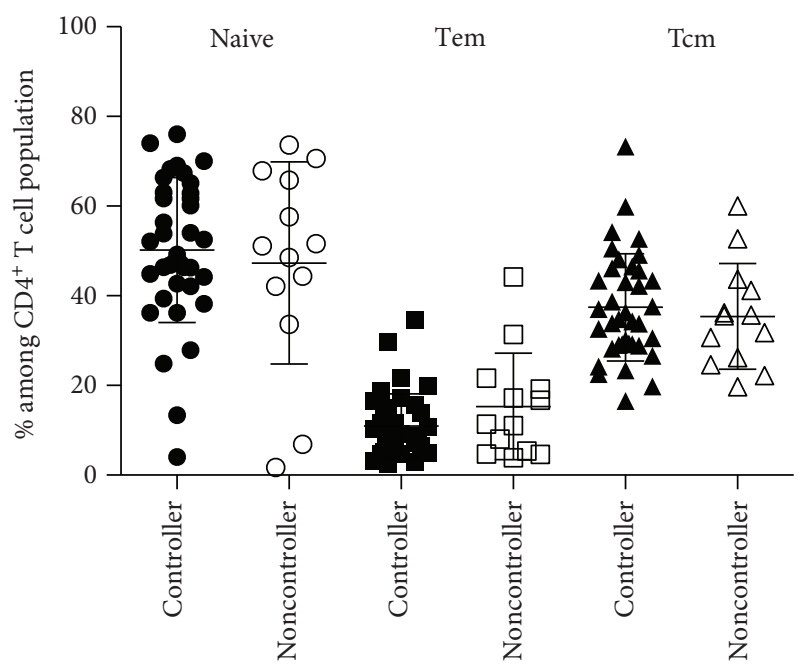

(b)

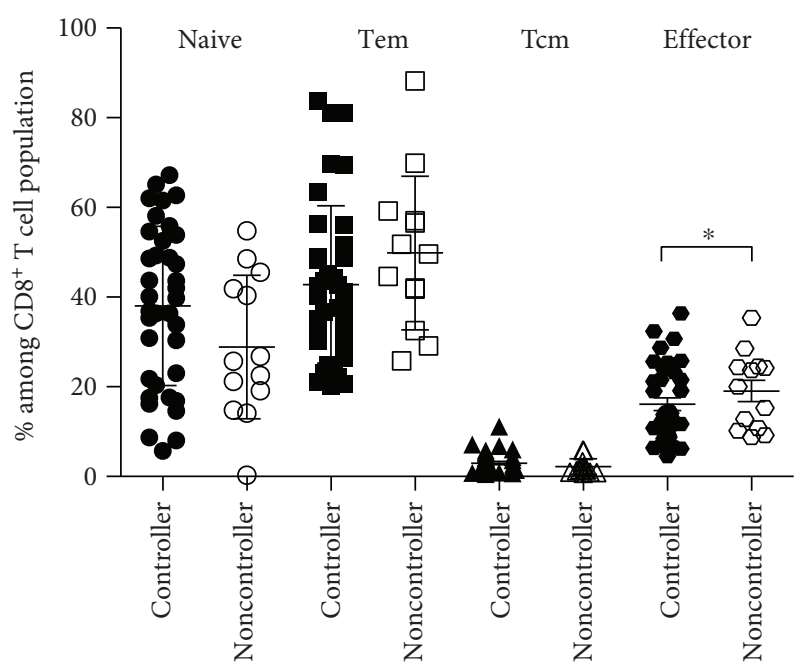

(d)

FIGURE 3: Comparison of T cell subsets between HIV-infected children with an undetectable viral load (controller group) and those with a virological failure (noncontroller group) detected by CD62L $(a, c)$ and CCR7 (b, d). Line bar represents average \pm SD; $*$ indicates significant difference at $P<0.05$. 

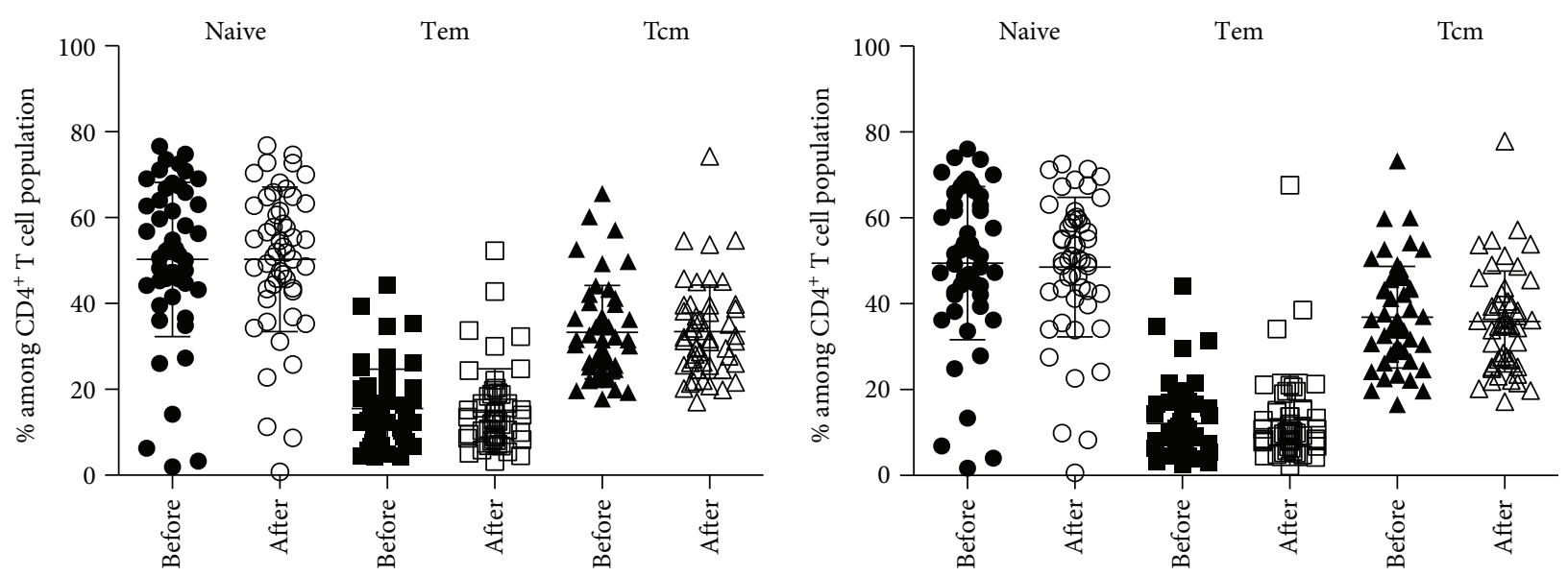

(a)

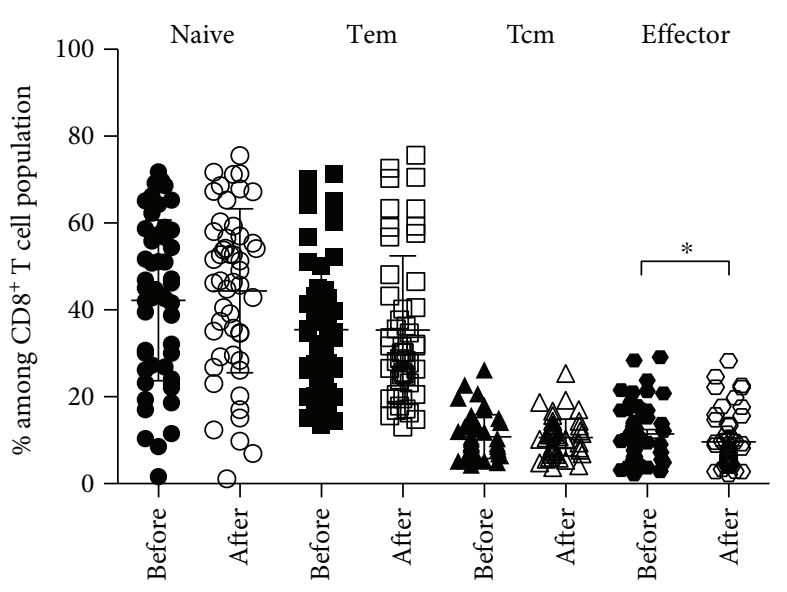

(c)

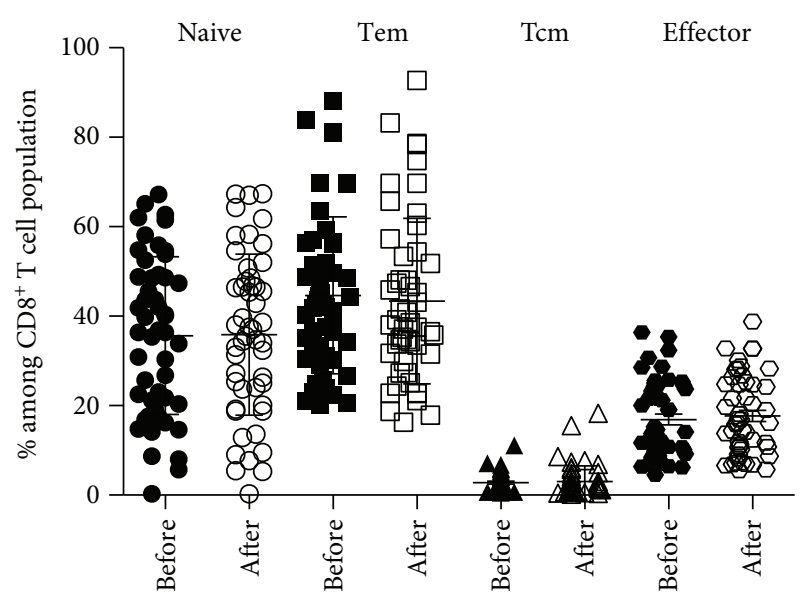

(d)

FIgURE 4: Comparison of T cell subsets before and after immunization in total population of HIV-infected patients detected by CD62L (a, c) and CCR7 $(b, d)$. Line bar represents average \pm SD; $*$ indicates significant difference at $P<0.05$.

into controller and noncontroller groups. Frequencies of $\mathrm{CD}^{+} \mathrm{T}$ cell subsets of controller and noncontroller groups are compared in Figures 3(a) and 3(b) when using CD62L and CCR7, respectively. There was no difference between the two different groups as well as the two different staining sets. Frequencies of $\mathrm{CD}^{+} \mathrm{T}$ cell subpopulations of the two groups when using the two $\mathrm{mAb}$ combinations are also presented in Figures 3(c) and 3(d). The data shows the same trend when using CD62L and CCR7. All subpopulations of controller and noncontroller groups gave the similar numbers, except effector cells. Effector cells in the controller group had a lower amount than those in the noncontroller group (10.6\% versus $13.8 \%$ when staining with CD62L and $16.1 \%$ versus $19.1 \%$ when staining with CCR7).

To evaluate the impact of immunization on T cell distribution, the whole study population was examined at two time points, before and after inoculation. Frequencies of $\mathrm{CD}_{4}^{+} \mathrm{T}$ cell subpopulations when using CD62L and CCR7, respectively, are presented in Figures 4(a) and 4(b), and similarly for $\mathrm{CD}^{+} \mathrm{T}$ cell subsets in Figures 4(c) and 4(d). Naïve, Tem, and Tcm cells of both $\mathrm{CD}^{+}$and $\mathrm{CD} 8^{+}$showed no difference between before and after vaccination from the two $\mathrm{mAb}$ sets. Effector $\mathrm{CD}^{+} \mathrm{T}$ cells before immunization were in greater amount than those after immunization (11.5\% versus 9.6\%) when using CD62L. Effector $\mathrm{CD}^{+} \mathrm{T}$ cells before immunization were, however, similar to those after immunization when using CCR7. It is worth noting that using either CD62L or CCR7 did not make any difference to $\mathrm{T}$ cell subset distribution patterns.

Due to a significant decrease in effector $\mathrm{CD} 8^{+} \mathrm{T}$ cells after vaccination (Figure 4(c)), further investigation for the effect of viral replication was conducted in these effector $\mathrm{CD} 8^{+} \mathrm{T}$ cells. For the controller group, effector cells before vaccination with the amount of $10.6 \pm 6.4 \%$ were reduced to 8.9 $\pm 6.0 \%$ after vaccination. The noncontroller group, however, had almost an identical profile of effector cells between before and after immunization (data not shown). Therefore, viral replication does not affect the change of effector cells.

In addition, frequencies and absolute counts of total $\mathrm{CD}^{+}{ }^{+}$and $\mathrm{CD}^{+}{ }^{+} \mathrm{T}$ cells were also compared (Table 1). There was no significant difference between before and after immunization in the controller group, noncontroller group, and total population.

3.3. Correlation between T Cell Subsets and CD4 Count. Correlations between $\mathrm{CD}^{+}$and $\mathrm{CD}^{+} \mathrm{T}$ cells (i.e., absolute 
TABLE 1: Percentages of CD4 and CD8 and absolute CD4 and CD8 counts before and after immunization in the controller and noncontroller groups and total population.

\begin{tabular}{|c|c|c|c|c|c|c|}
\hline \multirow[b]{2}{*}{ Group } & \multicolumn{2}{|c|}{ Controller group $(n=37)$} & \multicolumn{2}{|c|}{ Noncontroller group $(n=13)$} & \multicolumn{2}{|c|}{ Total population $(n=50)$} \\
\hline & $\begin{array}{c}\text { Before } \\
\text { immunization }\end{array}$ & $\begin{array}{c}\text { After } \\
\text { immunization }\end{array}$ & $\begin{array}{c}\text { Before } \\
\text { immunization }\end{array}$ & $\begin{array}{c}\text { After } \\
\text { immunization }\end{array}$ & $\begin{array}{c}\text { Before } \\
\text { immunization }\end{array}$ & $\begin{array}{c}\text { After } \\
\text { immunization }\end{array}$ \\
\hline$\% \mathrm{CD} 4$ & $29.3 \pm 9.0$ & $30.7 \pm 8.5$ & $25.7 \pm 12.3$ & $25.9 \pm 14.2$ & $28.4 \pm 9.9$ & $29.5 \pm 10.3$ \\
\hline $\begin{array}{l}\text { Absolute CD4 count } \\
(\text { cells } / \mu \mathrm{L})\end{array}$ & $982 \pm 539$ & $1008 \pm 585$ & $1073 \pm 992$ & $1082 \pm 914$ & $1006 \pm 675$ & $1027 \pm 676$ \\
\hline$\% \mathrm{CD} 8$ & $39.4 \pm 10.0$ & $38.6 \pm 9.0$ & $38.6 \pm 10.1$ & $41.0 \pm 12.8$ & $39.2 \pm 10.0$ & $39.3 \pm 10.0$ \\
\hline $\begin{array}{l}\text { Absolute CD8 count } \\
(\text { cells } / \mu \mathrm{L})\end{array}$ & $1255 \pm 478$ & $1219 \pm 546$ & $1322 \pm 526$ & $1478 \pm 573$ & $1273 \pm 487$ & $1286 \pm 559$ \\
\hline
\end{tabular}

Note: data are shown as average \pm SD.

TABLE 2: Correlations between each of T cell subsets and percentages of CD4 and CD8 and absolute CD4 and CD8 counts in ART-treated HIV-infected children after immunization $(n=50)$.

\begin{tabular}{|c|c|c|c|c|c|}
\hline \multirow[b]{2}{*}{ Marker } & \multirow[b]{2}{*}{ T cell subset } & \multicolumn{4}{|c|}{ Correlation $(r)$} \\
\hline & & $\begin{array}{l}\text { Versus } \\
\% \text { CD4 } \\
\end{array}$ & $\begin{array}{c}\text { Versus } \\
\text { absolute CD4 count }\end{array}$ & $\begin{array}{l}\text { Versus } \\
\text { \% CD8 }\end{array}$ & $\begin{array}{c}\text { Versus } \\
\text { absolute CD8 count }\end{array}$ \\
\hline \multirow{3}{*}{ CD45RA/CD62L } & Naïve $\mathrm{CD} 4^{+} \mathrm{T}$ cells & $0.6427^{*}$ & $0.7127^{*}$ & $-0.5365^{*}$ & 0.1302 \\
\hline & Tem $\mathrm{CD}^{+} \mathrm{T}$ cells & $-0.6430^{*}$ & $-0.7190^{*}$ & $0.6179^{*}$ & -0.1103 \\
\hline & $\mathrm{Tcm} \mathrm{CD}^{+} \mathrm{T}$ cells & $-0.4515^{*}$ & $-0.5547^{*}$ & $0.3462^{*}$ & -0.1627 \\
\hline \multirow{4}{*}{ CD45RA/CD62L } & Naïve $\mathrm{CD}^{+} \mathrm{T}$ cells & $0.5579^{*}$ & $0.5048^{*}$ & $-0.5677^{*}$ & -0.1335 \\
\hline & Effector $\mathrm{CD}^{+} \mathrm{T}$ cells & -0.1930 & -0.0072 & 0.2275 & $0.3175^{*}$ \\
\hline & Tem CD8 ${ }^{+} \mathrm{T}$ cells & $-0.5008^{*}$ & $-0.4741^{*}$ & $0.5756^{*}$ & 0.0858 \\
\hline & $\mathrm{Tcm} \mathrm{CD}^{+} \mathrm{T}$ cells & 0.0232 & -0.0745 & -0.1979 & -0.2180 \\
\hline \multirow{3}{*}{ CD45RA/CCR7 } & Naïve $\mathrm{CD} 4^{+} \mathrm{T}$ cells & $0.6865^{*}$ & $0.7184^{*}$ & $-0.5362^{*}$ & 0.0787 \\
\hline & Tem $\mathrm{CD}^{+} \mathrm{T}$ cells & $-0.7583^{*}$ & $-0.6958^{*}$ & $0.6892^{*}$ & 0.0806 \\
\hline & $\mathrm{Tcm} \mathrm{CD} 4^{+} \mathrm{T}$ cells & $-0.3670^{*}$ & $-0.4740^{*}$ & $0.2817^{*}$ & -0.1466 \\
\hline \multirow{4}{*}{ CD45RA/CCR7 } & Naïve $\mathrm{CD}^{+} \mathrm{T}$ cells & $0.5554^{*}$ & $0.4272^{*}$ & $-0.5223^{*}$ & -0.2269 \\
\hline & Effector $\mathrm{CD}^{+} \mathrm{T}$ cells & -0.0085 & 0.1533 & -0.0547 & $0.2947^{*}$ \\
\hline & Tem $\mathrm{CD} 8^{+} \mathrm{T}$ cells & $-0.5335^{*}$ & $-0.4887^{*}$ & $0.5583^{*}$ & 0.1208 \\
\hline & $\mathrm{Tcm} \mathrm{CD}^{+} \mathrm{T}$ cells & $0.3298^{*}$ & $0.3430^{*}$ & $-0.3485^{*}$ & -0.0199 \\
\hline
\end{tabular}

Note: *significant difference at $P<0.05$.

$\mathrm{CD}^{+}$and $\mathrm{CD}{ }^{+}$counts and their percentages) and their subsets (i.e., naïve, effector, Tem, and Tcm cells) from the whole subject population $(n=50)$ after immunization were analyzed and are shown in Table 2 . A relationship of only absolute $\mathrm{CD} 4$ count with all $\mathrm{CD} 4^{+}$subsets and naïve $\mathrm{CD} 8^{+} \mathrm{T}$ cells was found. There were little differences of the data obtained from CD62L compared to CCR7.

\section{Discussion}

In order to identify $\mathrm{T}$ cell subpopulations, immunofluorescent staining with CD45RA and CD45RO has been commonly used to classify naïve and memory cells in $\mathrm{CD}^{+}$ and $\mathrm{CD}^{+}$. Sallusto et al. reported that memory $\mathrm{CD}^{+} \mathrm{T}$ cells were able to be further divided into $\mathrm{Tcm}$ and Tem cells by detecting expressions of two lymph node homing receptors of CD62L and CCR7 [12]. Tcm cells showed no expression in CD45RA and expressed both CD62L and CCR7 $\left(\mathrm{CD} 45 \mathrm{RA}^{-} \mathrm{CD}^{-} 2 \mathrm{~L}^{+} \mathrm{CCR}^{+}\right)$, resulting in the cell capability of returning to the lymph node. Tem cells, on the other hand, did not express all those markers (CD45RA ${ }^{-} \mathrm{CD} \mathrm{L}^{-} \mathrm{CCR7}^{-}$), causing the lack of that cell ability and remaining in bloodstreams, spleens, and nonlymphoid tissues.

Our study distinguishes two important points on how the markers' utilization affects a detectable ability of memory $\mathrm{T}$ cell population when using CD62L and CCR7. The results firstly showed that frequencies of $\mathrm{CD} 2 \mathrm{~L}^{+}$or $\mathrm{CCR}^{+}$in Tcm cells and CD62 $\mathrm{L}^{-}$or CCR7 ${ }^{-}$in Tem cells are not necessarily equal. In $\mathrm{CD}^{+}$population, Tem cells using CD62L had greater amount than those using CCR7 and Tcm cells showed the opposite outcomes. Tem and Tcm cells in $\mathrm{CD}^{+}$population were vice versa to those in $\mathrm{CD} 4^{+}$. Secondly, $\mathrm{Tcm}$ cells in $\mathrm{CD}^{+}$and $\mathrm{CD}^{+}$populations can also be identified in more than one pattern when simultaneously stained with CD62L and CCR7. Tcm CD4 ${ }^{+}$cells were able to be characterized with the expressions of CD45RA ${ }^{-} \mathrm{CD} 2 \mathrm{~L}^{+} \mathrm{CCR}^{+}$, $\mathrm{CD} 4 \mathrm{RA}^{-} \mathrm{CD}^{-} \mathrm{L}^{+} \mathrm{CCR}^{-}$, and CD45RA ${ }^{-} \mathrm{CD}^{-} 2 \mathrm{~L}^{-} \mathrm{CCR7}^{+}$, whereas identification of $\mathrm{Tcm} \mathrm{CD} 8^{+}$cells showed the same patterns but excluding the latter (data not shown). 
In an effort to understand the impact of viral replication and immunization on ART-treated HIV-infected children, the effect of ART itself on T cell subset distribution has to be primarily established. There are a few studies conducted in children, while most investigations were performed in adult patients. Chen et al. found that naïve $\left(\mathrm{CD} 45 \mathrm{RA}^{+}\right.$ $\mathrm{CCR}^{+}$) and $\mathrm{Tcm}$ cells in $\mathrm{CD}^{+}$population dramatically reduced, whereas Tem cells increased in HIV-infected patients [13]. More evidence also supported the previous finding that Tem cells were also abundantly found in $\mathrm{CD}^{+}$ T cells together with a low level of Tcm cells $[14,15]$. As far as the efficacy of HAART is concerned, HAART inhibits viral replication and increases numbers of $\mathrm{CD}^{+} \mathrm{T}$ cells [16-18]. When further focusing on the change of $\mathrm{T}$ cell subsets, naïve $\mathrm{CD}^{+}$and $\mathrm{CD}^{+}{ }^{+} \mathrm{T}$ cells increased and memory $\mathrm{CD}{ }^{+}{ }^{+} \mathrm{T}$ cells significantly decreased [19]. An increase in naïve $\mathrm{CD}^{+} \mathrm{T}$ cells and a decrease in memory $\mathrm{CD} 4^{+} \mathrm{T}$ cells were also observed in HIV-infected children receiving HAART for 44 weeks [20].

Our study concurs with the previous findings that naïve cells, followed by Tcm and Tem cells, were predominantly found in $\mathrm{CD}^{+}{ }^{+} \mathrm{T}$ cells in HIV-infected children treated with ART. $\mathrm{CD}^{+}$population, however, showed differently as Tem cells were in majority, followed by naïve, effector, and Tcm cells.

Concerning viral replication affecting $\mathrm{T}$ cell subpopulations, Anselmi et al. found that only naïve $\mathrm{T}$ cells in HIVinfected children who had a virological failure after HAART initiation were higher than those in the patients who had a controllable viral load [21]. However, our results did not support that. We found no differences in frequency of all $\mathrm{CD} 4^{+}$ and most $\mathrm{CD}^{+} \mathrm{T}$ cell subsets (i.e., naïve, Tem, and $\mathrm{Tcm}$ cells) between the controller (having a controllable viral load, $<40$ copies $/ \mathrm{mL}$ ) and noncontroller (having a virological failure, $\geq 40$ copies $/ \mathrm{mL}$ ) groups. Only the frequency of effector $\mathrm{CD}^{+} \mathrm{T}$ cells in the controller group was higher than that in the noncontroller group. We then suggest that a transient increase in viral replication does not significantly change naïve, effector, and memory $\mathrm{T}$ cells.

When the influenza vaccine was inoculated, Gunthard et al. found that naïve $\mathrm{CD} 4^{+} \mathrm{T}$ cells transiently decreased and activated memory $\mathrm{CD}^{+} \mathrm{T}$ cells increased in healthy volunteers [22]. For HIV-infected patients, on the other hand, naive cells remained the same and activated memory T cells were reduced before returning to the baseline after 8 weeks. Another investigation also reported that naïve and memory $\mathrm{T}$ cells had no significant difference when inoculated with tetanus vaccines [23]. Our study complies with the previous findings as we found only effector $\mathrm{CD} 8^{+} \mathrm{T}$ cells notably decreased in the controller group after influenza vaccination and no change in the noncontroller group. It is then suggested that viral replication has no influence on the alteration of T cell subsets in ART-treated HIV-infected children after immunization. Likewise, immunization with the influenza A (H1N1) 2009 vaccine does not affect $\mathrm{T}$ cell subset distribution in ART-treated HIV-infected children.

We also verified the correlation between $T$ cell subset frequencies and absolute counts of CD4 and CD8. We found a positive relationship of absolute CD4 count with naïve $\mathrm{CD} 4^{+}$ and $\mathrm{CD}^{+} \mathrm{T}$ cells, suggesting that ART-treated patients with a high $\mathrm{CD}^{+} \mathrm{T}$ cell level are able to maintain a high naïve $\mathrm{T}$ cell level. However, the origin of naïve $\mathrm{T}$ cells remains unclear whether derived from new generation of $\mathrm{T}$ cells or redistributed from somewhere else. In contrast, our result showed a negative correlation between absolute CD4 count and Tcm cells, which differs from a study showing that Tcm cells were maintained in patients who can control viral replication without any antiretroviral treatment [24]. These different observational patterns suggest different mechanisms controlling T cell subset dynamic between antiretroviral-treated patients and patients who can naturally control viral replication.

\section{Conclusions}

This is the investigation of the impact of viral replication and immunization on individual naïve, effector, effector memory, and central memory $\mathrm{T}$ cell subpopulations from both $\mathrm{CD} 4^{+}$ and $\mathrm{CD}^{+} \mathrm{T}$ cells in ART-treated HIV-infected children. Naïve cells were predominant in $\mathrm{CD} 4^{+} \mathrm{T}$ cells, whereas effector memory cells were mainly found in $\mathrm{CD}^{+} \mathrm{T}$ cells in the patients without vaccination. No significant difference was observed between the patients with controllable and noncontrollable viral loads, except effector $\mathrm{CD} 8^{+} \mathrm{T}$ cells, suggesting that a transient increase in viral replication does not affect the $\mathrm{T}$ cell distribution. This is also confirmed by the results after inoculation of the influenza A (H1N1) 2009 vaccine, which shows that $\mathrm{T}$ cell distribution did not change in the patients with virological failure. Immunization also did not affect all $\mathrm{T}$ cell subpopulations, except effector $\mathrm{CD}{ }^{+} \mathrm{T}$ cells in the patients with controllable viral loads. Therefore, our finding can ensure physicians that the immunization of influenza A (H1N1) 2009 vaccine is safe to be used together with ART in HIV-infected children. Moreover, a correlation between $\mathrm{T}$ cell subset frequencies and absolute counts of CD4 and CD8, which are generally observed for disease progress, has been verified. Only naïve $\mathrm{CD}^{+}$and $\mathrm{CD}^{+} \mathrm{T}$ cells had a positive relationship with absolute CD4 count. The classical CD4 count can thus be useful for prediction of naïve $\mathrm{T}$ cell level in HIV-infected patients responding to ART.

\section{Disclosure}

The part of this manuscript entitled "Identification of naïve and memory $\mathrm{T}$ cell subsets in antiretroviral-treated HIVinfected children before and after immunization" was accepted to be an e-poster viewing at the 34th Annual Meeting of the European Society for Paediatric Infectious Disease in Brighton, UK, during 11-14 May 2016.

\section{Conflicts of Interest}

The authors certify that there is no conflict of interests with any financial organizations regarding the material discussed in this study.

\section{Acknowledgments}

The authors gratefully acknowledge the kind cooperation of the HIV-infected patients. They also thank the primary care 
physicians, Dr. Orasri Wittawatmongkol and Dr. Kulkanya Chokephaibulkit, and nurses who worked hard in providing them important clinical support for this study. They gratefully appreciate the technical assistance from Miss Petai Unpol and Miss Michittra Boonchan for flow cytometric analyses. Palanee Ammaranond is supported by the Ratchadaphiseksomphot Endowment Fund of Chulalongkorn University (RES560530214-HR). Premrutai Thitilertdecha, Ladawan Khowawisetsut, and Nattawat Onlamoon are supported by the Chalermphrakiat Grant from the Faculty of Medicine Siriraj Hospital.

\section{References}

[1] J. V. Giorgi and R. Detels, "T-cell subset alterations in HIVinfected homosexual men: NIAID Multicenter AIDS cohort study," Clinical Immunology and Immunopathology, vol. 52, no. 1, pp. 10-18, 1989.

[2] R. L. Rabin, M. Roederer, Y. Maldonado, A. Petru, L. A. Herzenberg, and L. A. Herzenberg, "Altered representation of naive and memory CD8 T cell subsets in HIV-infected children," The Journal of Clinical Investigation, vol. 95, no. 5, pp. 2054-2060, 1995.

[3] M. Roederer, J. G. Dubs, M. T. Anderson, P. A. Raju, L. A. Herzenberg, and L. A. Herzenberg, "CD8 naive T cell counts decrease progressively in HIV-infected adults," The Journal of Clinical Investigation, vol. 95, no. 5, pp. 2061-2066, 1995.

[4] N. G. Pakker, D. W. Notermans, R. J. de Boer et al., "Biphasic kinetics of peripheral blood $\mathrm{T}$ cells after triple combination therapy in HIV-1 infection: a composite of redistribution and proliferation," Nature Medicine, vol. 4, no. 2, pp. 208214, 1998.

[5] M. Plana, F. Garcia, T. Gallart et al., "Immunological benefits of antiretroviral therapy in very early stages of asymptomatic chronic HIV-1 infection," Aids, vol. 14, no. 13, pp. 19211933, 2000.

[6] M. J. Glesby, D. R. Hoover, H. Farzadegan, J. B. Margolick, and A. J. Saah, "The effect of influenza vaccination on human immunodeficiency virus type 1 load: a randomized, doubleblind, placebo-controlled study," The Journal of Infectious Diseases, vol. 174, no. 6, pp. 1332-1336, 1996.

[7] S. A. Tasker, W. A. O'Brien, J. J. Treanor et al., "Effects of influenza vaccination in HIV-infected adults: a double-blind, placebo-controlled trial," Vaccine, vol. 16, no. 9-10, pp. 1039-1042, 1998.

[8] K. R. Fowke, R. D'Amico, D. N. Chernoff et al., "Immunologic and virologic evaluation after influenza vaccination of HIV-1infected patients," Aids, vol. 11, no. 8, pp. 1013-1021, 1997.

[9] P. S. Sullivan, D. L. Hanson, M. S. Dworkin, J. L. Jones, and J. W. Ward, "Effect of influenza vaccination on disease progression among HIV-infected persons," Aids, vol. 14, no. 17, pp. 2781-2785, 2000.

[10] A. M. Iorio, D. Francisci, B. Camilloni et al., "Antibody responses and HIV-1 viral load in HIV-1-seropositive subjects immunised with either the MF59-adjuvanted influenza vaccine or a conventional non-adjuvanted subunit vaccine during highly active antiretroviral therapy," Vaccine, vol. 21, no. 2526, pp. 3629-3637, 2003.

[11] G. Gabutti, M. Guido, P. Durando et al., "Safety and immunogenicity of conventional subunit and MF59-adjuvanted influenza vaccines in human immunodeficiency virus-1- seropositive patients," The Journal of International Medical Research, vol. 33, no. 4, pp. 406-416, 2005.

[12] F. Sallusto, D. Lenig, R. Forster, M. Lipp, and A. Lanzavecchia, "Two subsets of memory T lymphocytes with distinct homing potentials and effector functions," Nature, vol. 401, no. 6754, pp. 708-712, 1999.

[13] G. Chen, P. Shankar, C. Lange et al., "CD8 T cells specific for human immunodeficiency virus, Epstein-Barr virus, and cytomegalovirus lack molecules for homing to lymphoid sites of infection," Blood, vol. 98, no. 1, pp. 156-164, 2001.

[14] P. Champagne, G. S. Ogg, A. S. King et al., "Skewed maturation of memory HIV-specific CD8 T lymphocytes," Nature, vol. 410, no. 6824, pp. 106-111, 2001.

[15] Y. M. Mueller, S. C. De Rosa, J. A. Hutton et al., "Increased CD95/Fas-induced apoptosis of HIV-specific CD8(+) T cells," Immunity, vol. 15, no. 6, pp. 871-882, 2001.

[16] A. Wiznia, K. Stanley, P. Krogstad et al., "Combination nucleoside analog reverse transcriptase inhibitor(s) plus nevirapine, nelfinavir, or ritonavir in stable antiretroviral therapyexperienced HIV-infected children: week 24 results of a randomized controlled trial-PACTG 377. Pediatric AIDS Clinical Trials Group 377 Study Team,” AIDS Research and Human Retroviruses, vol. 16, no. 12, pp. 1113-1121, 2000.

[17] P. Krogstad, S. Lee, G. Johnson et al., "Nucleoside-analogue reverse-transcriptase inhibitors plus nevirapine, nelfinavir, or ritonavir for pretreated children infected with human immunodeficiency virus type 1," Clinical Infectious Diseases, vol. 34, no. 7, pp. 991-1001, 2002.

[18] S. Resino, J. M. Bellon, D. Gurbindo et al., "Viral load and CD4 $+\mathrm{T}$ lymphocyte response to highly active antiretroviral therapy in human immunodeficiency virus type 1-infected children: an observational study," Clinical Infectious Diseases, vol. 37, no. 9, pp. 1216-1225, 2003.

[19] S. Resino, I. Galan, A. Perez et al., "HIV-infected children with moderate/severe immune-suppression: changes in the immune system after highly active antiretroviral therapy," Clinical and Experimental Immunology, vol. 137, no. 3, pp. 570-577, 2004.

[20] H. M. Rosenblatt, K. E. Stanley, L. Y. Song et al., "Immunological response to highly active antiretroviral therapy in children with clinically stable HIV-1 infection," The Journal of Infectious Diseases, vol. 192, no. 3, pp. 445-455, 2005.

[21] A. Anselmi, D. Vendrame, O. Rampon, C. Giaquinto, M. Zanchetta, and A. De Rossi, "Immune reconstitution in human immunodeficiency virus type 1-infected children with different virological responses to anti-retroviral therapy," Clinical and Experimental Immunology, vol. 150, no. 3, pp. 442-450, 2007.

[22] H. F. Gunthard, J. K. Wong, C. A. Spina et al., "Effect of influenza vaccination on viral replication and immune response in persons infected with human immunodeficiency virus receiving potent antiretroviral therapy," The Journal of Infectious Diseases, vol. 181, no. 2, pp. 522-531, 2000.

[23] T. N. Dieye, P. S. Sow, T. Simonart et al., "Immunologic and virologic response after tetanus toxoid booster among HIV1- and HIV-2-infected Senegalese individuals," Vaccine, vol. 20, no. 5-6, pp. 905-913, 2001.

[24] S. J. Potter, C. Lacabaratz, O. Lambotte et al., "Preserved central memory and activated effector memory CD4+ T-cell subsets in human immunodeficiency virus controllers: an ANRS EP36 study," Journal of Virology, vol. 81, no. 24, pp. 13904-13915, 2007. 


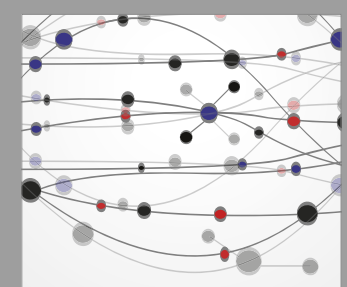

The Scientific World Journal
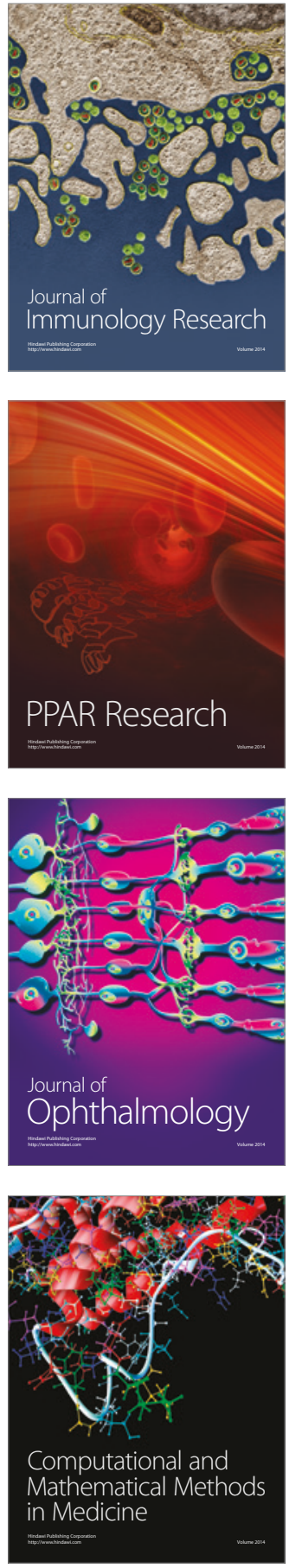

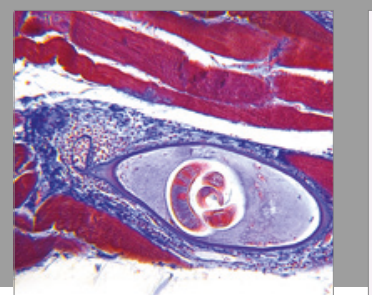

Gastroenterology Research and Practice
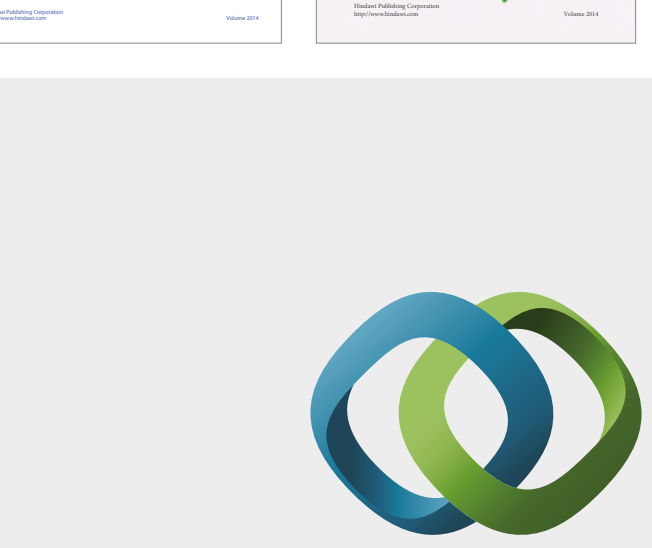

\section{Hindawi}

Submit your manuscripts at

https://www.hindawi.com
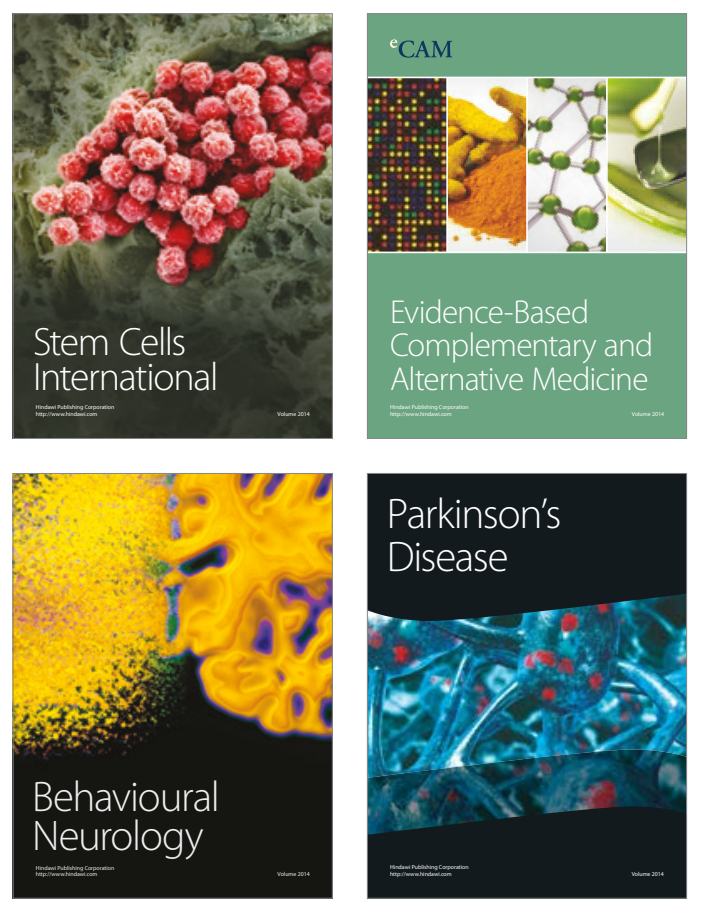
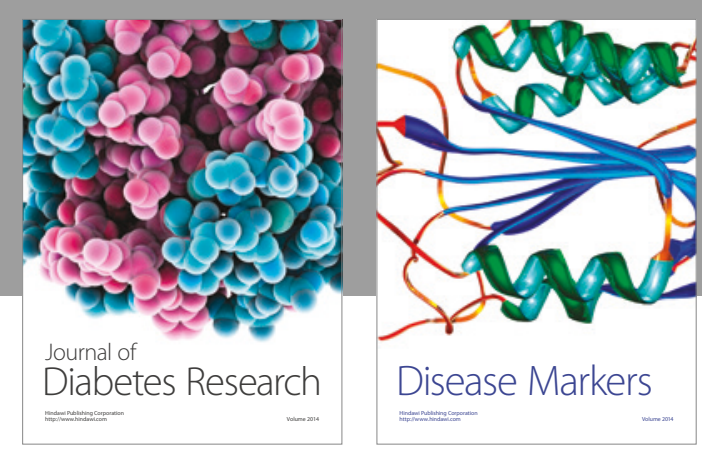

Disease Markers
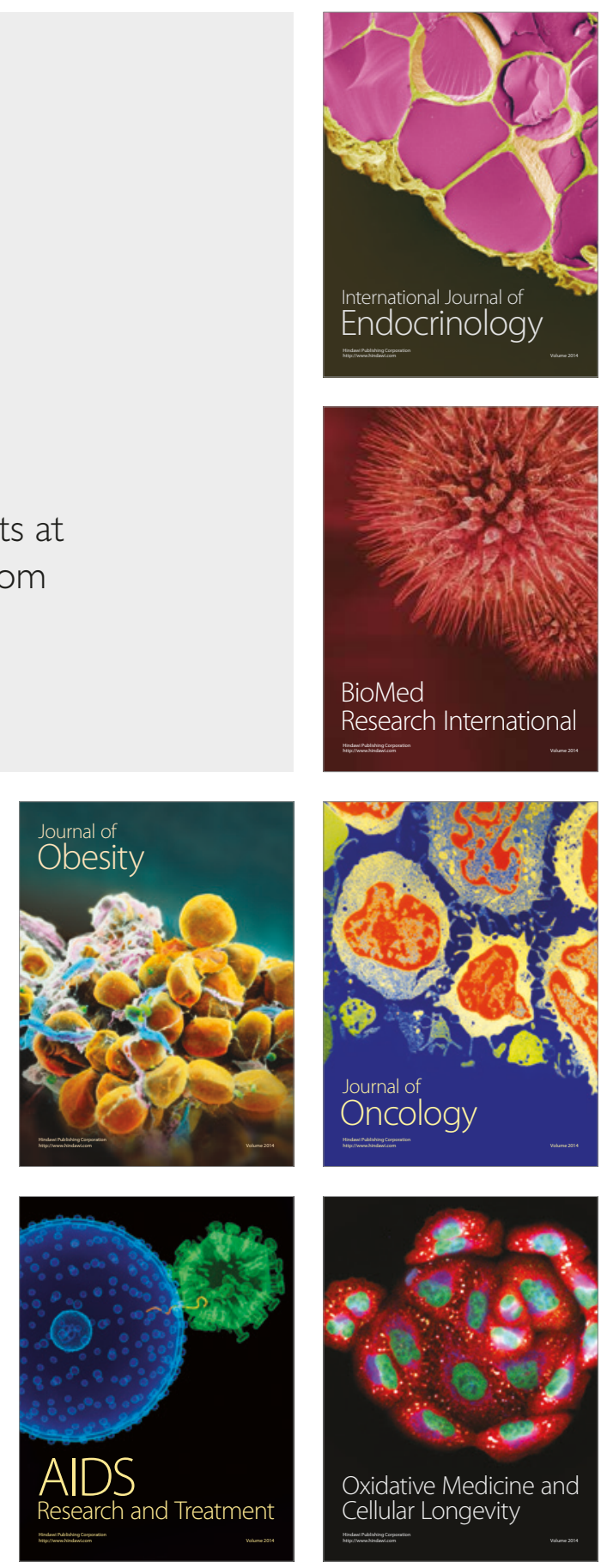